\title{
Effect of Ozone Stress on the Absorption, Distribution, and Utilization of Nitrogen in Rice under Different Planting Densities
}

\author{
B. PENG ${ }^{1,2}, \mathrm{P} . \mathrm{LI}^{2}$, S. $\mathrm{LAI}^{2}$, Y. WANG ${ }^{2}$, L. YANG ${ }^{2, *}$ and Y. WANG ${ }^{2}$ \\ ${ }^{1}$ Jiangsu Key Laboratory of Biochemistry and Biotechnology of Marine Wetland, \\ Yancheng Institute of Technology, Yancheng 224051, China \\ ${ }^{2}$ Key Laboratory of Crop Genetics and Physiology of Jiangsu Province, Yangzhou University, \\ Yangzhou 225009, China
}

(Received 13 April 2017; Accepted 10 July 2018;

Communicated by S. Gottwald and H. Grausgruber)

\begin{abstract}
High ozone $\left(\mathrm{O}_{3}\right)$ can cause great damage to plants. However, the effect of high $\mathrm{O}_{3}$ on nitrogen $(\mathrm{N})$ absorption, distribution, and utilization in rice at different growth stages under different planting densities is poorly understood. In the present study, a conventional cultivar (Yangdao 6) and a hybrid cultivar (II You 084) with different planting densities were exposed to an elevated amount of $\mathrm{O}_{3}\left(\mathrm{E}-\mathrm{O}_{3} ; 50 \%\right.$ higher than that of the control, $\left.\mathrm{C}-\mathrm{O}_{3}\right)$ under a freeair gas concentration enrichment (FACE) system. $\mathrm{N}$ absorption, distribution, and utilization of the green leaves, stems, and shoots at tillering, jointing heading, and maturity were investigated. Results showed that $\mathrm{E}-\mathrm{O}_{3}$ significantly increased the $\mathrm{N}$ content in the shoots of Yangdao 6 by $7.5 \%, 12.7 \%$, and $19.6 \%$, respectively, at jointing, heading, and maturity. Also, the $\mathrm{N}$ content in the shoots of II You 084 increased by $5.4 \%, 6.5 \%$, and $8.4 \%$ at the corresponding growth stage upon $\mathrm{E}_{-} \mathrm{O}_{3}$ application. $\mathrm{E}-\mathrm{O}_{3}$ significantly decreased $\mathrm{N}$ accumulation of II You 084 by $8.3 \%, 4.9 \%, 4.7 \%$, and $19.2 \%$, respectively, at tillering, jointing, heading, and maturity. Further, $\mathrm{E}-\mathrm{O}_{3}$ had a decreasing effect on the $\mathrm{N}$ distribution in green leaves $(p \leq 0.05)$ of both cultivars, but exerted an increasing effect on that in the stems of both cultivars $(p \leq 0.05)$. In addition, $\mathrm{E}_{-} \mathrm{O}_{3}$ significantly decreased the $\mathrm{N}$ use efficiency (NUE) for biomass of the two cultivars in all growth stages. These results revealed that $\mathrm{E}-\mathrm{O}_{3}$ could increase the $\mathrm{N}$ content in rice plants but decrease the $\mathrm{N}$ accumulation and utilization in both cultivars. The effects of $\mathrm{E}-\mathrm{O}_{3}$ on $\mathrm{N}$ absorption, distribution, and utilization were not affected by planting density.
\end{abstract}

Keywords: rice, ozone, planting density, nitrogen

\section{Introduction}

Human activities have dramatically increased the concentration of near-ground ozone $\left(\mathrm{O}_{3}\right)$, leading to an average concentration of $\mathrm{O}_{3}$ in surface air that has exceeded the injury threshold of sensitive crops ( $\left.40 \mathrm{nl} \mathrm{L}^{-1}\right)$, causing visible damages to wild and cultivated plants and becoming a more and more serious problem (Feng and Kobayashi 2009). The atmospheric environmental changes including increased $\mathrm{O}_{3}$, have directly or indirectly

\footnotetext{
*Corresponding author; E-mail: lxyang@yzu.edu.cn
} 
given rise to a series of problems with respect to global food security, such as the decline of utilized land, changes in the ecological environment, decreased water use efficiency, decreased crop yields, and deterioration of crop quality (Zeng et al. 2008). The effect of $\mathrm{O}_{3}$ stress on the growth and yield of rice has been extensively studied (Ainsworth 2008; Yang et al. 2008; Tong et al. 2015). Most experiments in previous studies were based on one-factor tests, while only a few were factorial experiments that assessed the interaction between $\mathrm{O}_{3}$ and cultivation conditions (Yang et al. 2008; Luo et al. 2012). In addition, previous studies were mostly chamber-based (Jin et al. 2001; Chen et al. 2008; Yang et al. 2008). The narrow chamber and artificial isolated facilities, which disturb the microclimate around the plants, together with the marginal effect of chamber-based studies, would change the reaction level of crops in response to $\mathrm{O}_{3}$ stress. Unlike chamber-based studies, free-air gas concentration enrichment (FACE) studies were carried out under fully open air conditions, which is considered to be the optimal method by which to assess the actual effect of atmospheric composition on crop yield (Long et al. 2011).

Nitrogen $(\mathrm{N})$ is the main nutrient that plants need. Several studies about the effect of $\mathrm{O}_{3}$ stress on the content and distribution of $\mathrm{N}$ have been carried out in different crops (Chen et al. 2011; Zhao et al. 2015). Different cultivars exhibited different $\mathrm{N}$ uptake and partitioning. For example, Zheng et al. (2011) found that elevated $\mathrm{O}_{3}$ significantly increased the total $\mathrm{N}$ concentration in the milled hybrid rice cultivar Shanyou 63. In contrast, Kou et al. (2017) showed that elevated $\mathrm{O}_{3}$ led to significantly decreased grain production efficiency of $\mathrm{N}$ in Shanyou 63 and Liangyoupeijiu. These results revealed that the effects of evaluated $\mathrm{O}_{3}$ on the $\mathrm{N}$ uptakes and partitioning in tissues in rice were cultivardependent.

Conventional cultivar Yangdao 6 and hybrid cultivar II You 084 are the major rice varieties planted in eastern China. In eastern China, certain areas suffer from $\mathrm{O}_{3}$ pollution, having an $\mathrm{O}_{3}$ concentration greater than $150 \mathrm{ppb}$ (Shao et al. 2006). However, so far, no reports are available on the effects of $\mathrm{O}_{3}$ stress on $\mathrm{N}$ metabolism in these two rice varieties. In addition, plant density is an important factor that influences the growth and yield of plants. Some plant resistances are also related to plant density (Wu et al. 2015). Thus, in the present study, the effects of evaluated $\mathrm{O}_{3}$ on the $\mathrm{N}$ absorption, distribution, and utilization in Yangdao 6 and II You 084 with different densities were studied using a $\mathrm{O}_{3}$ FACE platform, in order to enlighten $\mathrm{N}$ metabolism and the regulatory role of plant densities and varieties at different growth stages in response to $\mathrm{O}_{3}$ stress.

\section{Materials and Methods}

\section{Experimental site and the ozone FACE platform}

The field trial was carried out at the ozone FACE experimental station in Xiaoji Town Seed Multiplication Farm (Jiangdu County, Jiangsu Province, China) (119 42'0"E, $32^{\circ} 35^{\prime} 5^{\prime \prime} \mathrm{N}, 5 \mathrm{~m}$ a.s.1.), with a mean annual rainfall of $980 \mathrm{~mm}$, mean annual evaporation over $1100 \mathrm{~mm}$, mean annual temperature of $14.9^{\circ} \mathrm{C}$, total annual sunshine duration over $2100 \mathrm{~h}$, and a frost-free period of 220 days. The land is under tillage and crop rotation of 
rice and winter wheat. The soil at the experiment site has a sandy-loamy texture according to the US classification (Soil Survey Staff 2003). The soil texture is mainly sandy, with a clay concentration of approximately $13.6 \%$ in the surface layer (Kuo et al. 2014). At the beginning of the experiment, the properties of the plow layer of soil $(0-15 \mathrm{~cm})$ were: 18.8 $\mathrm{g} \mathrm{kg}^{-1}$ organic carbon (C), $1.58 \mathrm{~g} \mathrm{~kg}^{-1}$ total $\mathrm{N}, 0.67 \mathrm{~g} \mathrm{~kg}^{-1}$ total phosphorus (P), $15.1 \mathrm{~g} \mathrm{~kg}^{-1}$ total potassium $(\mathrm{K}), 10.8 \mathrm{~g} \mathrm{~kg}^{-1}$ rapid available $\mathrm{P}, 72.1 \mathrm{~g} \mathrm{~kg}^{-1}$ rapid available $\mathrm{K}$, bulk density of $1.23 \mathrm{~g} \mathrm{~cm}^{-3}$, and $\mathrm{pH}$ of 7.3 (Pang et al. 2009).

The ozone FACE system included eight rings (diameter: $14 \mathrm{~m}$ ) with an available area of $120 \mathrm{~m}^{2}$. Four of the rings were experimental $\left(\mathrm{E}-\mathrm{O}_{3}\right)$ rings and the other four were control $\left(\mathrm{C}-\mathrm{O}_{3}\right)$ rings. The $\left(\mathrm{E}-\mathrm{O}_{3}\right)$ rings with target $\mathrm{O}_{3}$ concentrations were approximately $50 \%$ higher than those in the ambient atmosphere, and the four control rings did not receive $\mathrm{O}_{3}$ enrichment. The quantity and direction of the $\mathrm{O}_{3}$ release for each $\mathrm{E}-\mathrm{O}_{3}$ plot were controlled by a proportional integral derivative algorithm for computer feedback that compares the achieved $\mathrm{O}_{3}$ concentrations to target $\mathrm{O}_{3}$ concentrations with an $\mathrm{O}_{3}$ concentration monitor (Thermo Electron 49i, Thermo Fischer Scientific, Waltham, MA, USA), a data logger-controller, an anemometer, and a wind vane. The interval between each ring was more than $70 \mathrm{~m}$ to avoid cross-contamination. Pure $\mathrm{O}_{3}$ was released toward the center of the ozone FACE rings, 50-60 $\mathrm{cm}$ above the crop canopy. The ozone enrichment started from 9:00 to 16:00 every day from July 1 until rice maturity. No $\mathrm{O}_{3}$ was released on rainy days to limit acute damage to leaves. The $\mathrm{C}-\mathrm{O}_{3}$ concentrations in 2011 ranged from $5.8 \mathrm{nl}$ $\mathrm{L}^{-1}$ to $80.0 \mathrm{nl} \mathrm{L}^{-1}$, with an average concentration of $36.6 \mathrm{nl} \mathrm{L}^{-1}$. In contrast, E-O $\mathrm{O}_{3}$ concentrations in 2011 ranged from $7.7 \mathrm{nl} \mathrm{L}^{-1}$ to $119.3 \mathrm{nl} \mathrm{L}^{-1}$, and the average concentration was $46.4 \mathrm{nl} \mathrm{L}^{-1}$. For 2012, the mean concentration of $\mathrm{C}_{-} \mathrm{O}_{3}$ was $41.5 \mathrm{nl} \mathrm{L}^{-1}$, ranging from 9.3 to $100.1 \mathrm{nl} \mathrm{L}^{-1}$, and that of $\mathrm{E}_{-} \mathrm{O}_{3}$ was $51.4 \mathrm{nl} \mathrm{L}-1$, ranging from 11.4 to $134.9 \mathrm{nl} \mathrm{L}^{-1}$ (Fig. S1*).

\section{Plant material and data collection}

Test varieties used in this study were Yangdao 6 and II You 084, which were sown on 22nd May 2011 and 2012, respectively, and transplanted on June $21^{\text {st }}$. The $15 \mathrm{~g} / \mathrm{m}^{2}$ of $\mathrm{N}$ was applied was, along with $7 \mathrm{~g} / \mathrm{m}^{2}$ of $\mathrm{P}$ and $7 \mathrm{~g} / \mathrm{m}^{2}$ of $\mathrm{K}$. The following fertilizers were used: $150 \mathrm{~kg} \mathrm{~N} \mathrm{ha}{ }^{-1}$ as urea, $70 \mathrm{~kg} \mathrm{P} \mathrm{ha}^{-1}$ as superphosphate, and $70 \mathrm{~kg} \mathrm{~K} \mathrm{ha}^{-1}$ as potassium chloride. The $\mathrm{P}$ and $\mathrm{K}$ fertilizers were used before transplanting, urea was used at the before transplanting, tillering stage and panicle initiation stage in the ratio of 5:1:4. Transplanting density was low (LD; 16 seeds $\mathrm{m}^{-2}$, plant row spacing $25 \times 25 \mathrm{~cm}$ ), medium $\left(\mathrm{MD} ; 24\right.$ seeds $\mathrm{m}^{-2}$, plant row spacing $\left.16.7 \times 25 \mathrm{~cm}\right)$, and high $\left(\mathrm{HD} ; 32\right.$ seeds $\mathrm{m}^{-2}$, plant row spacing $12.5 \times 25 \mathrm{~cm}$ ). The experiment was laid out as split-split-plot design with $\mathrm{O}_{3}$ concentration as main plots and varieties and transplanting densities as subplots.

Six plants (hills) were randomly selected in each plot. Samples including green leaves, stem (including leaf sheath), and panicle (when applicable) were collected at tillering, jointing, heading, and maturity and dried $\left(105^{\circ} \mathrm{C}\right.$ fixing, $80^{\circ} \mathrm{C}$ stoving $\left.72 \mathrm{~h}\right)$ to calculate the dry matter accumulation. The material was further sifted, microwave digested (MARS,

*Further details about the Electronic Supplementary Material (ESM) can be found at the end of the article. 


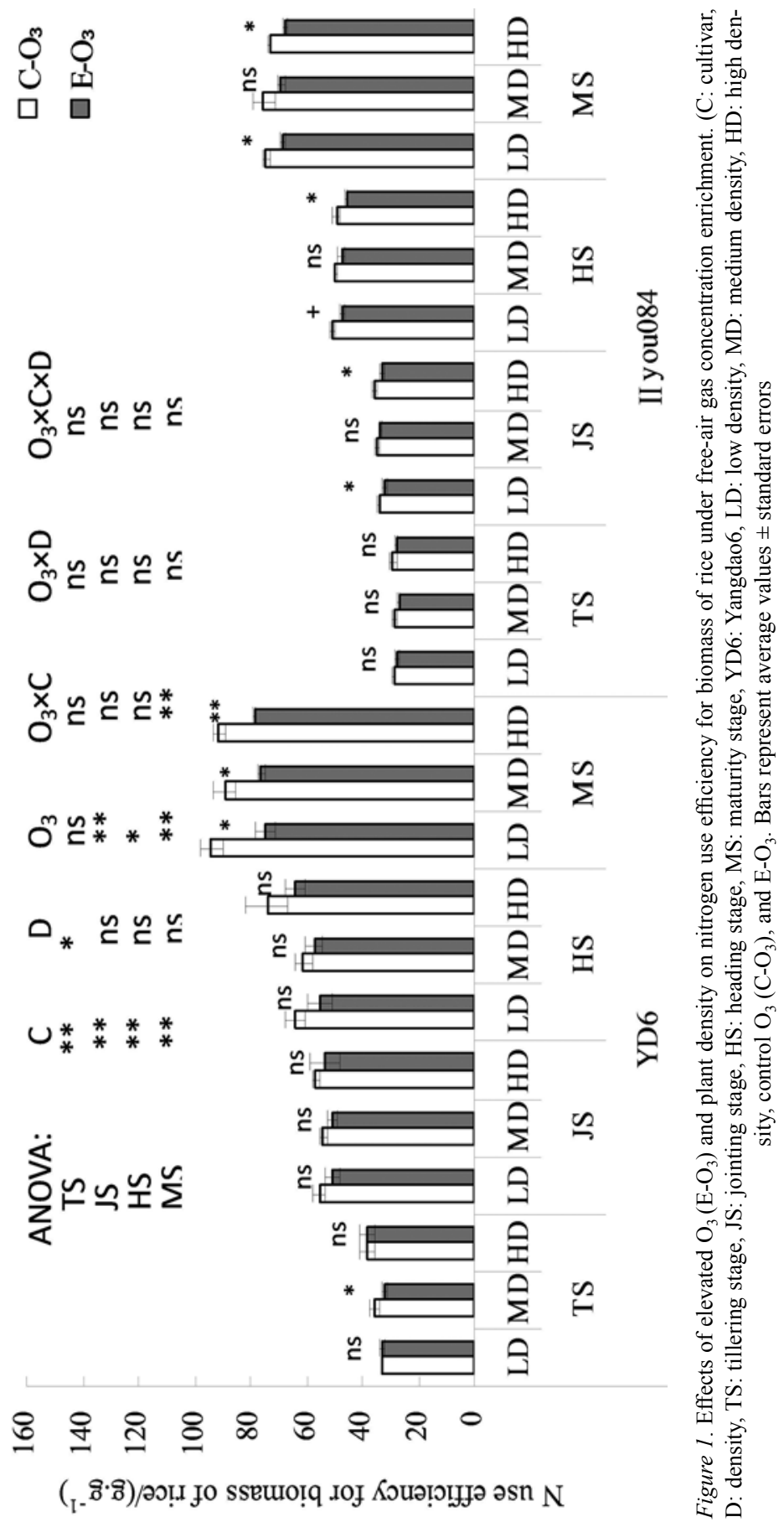

Cereal Research Communications 47, 2019 
CEM Corp. Matthews, NC). N content of each sample was measured using a Kjeltec ${ }^{\mathrm{TM}}$ 2300 (Foss Tecator, Högänäs, Sweden), and N accumulation was calculated accordingly.

$\mathrm{N}$ utilization efficiency (NUE), including nitrogen dry matter production efficiency, NUE for grain output, and $\mathrm{N}$ harvest index were calculated using the following equations:

$\mathrm{N}$ dry matter production efficiency $=$ amount of dry matter accumulation in each growth period/amount of $\mathrm{N}$ accumulation in shoot $\left(\mathrm{g} \mathrm{g}^{-1}\right)$.

NUE for grain output $=$ grain output/amount of $\mathrm{N}$ accumulation in shoot of maturation stage $\left(\mathrm{g} \mathrm{g}^{-1}\right)$.

$\mathrm{N}$ harvest index $=$ amount of $\mathrm{N}$ accumulation in the grain/amount of $\mathrm{N}$ accumulation in shoot of maturation stage $\left(\mathrm{g} \mathrm{g}^{-1}\right)$.

\section{Statistical analysis}

The split-split-plot statistical design was used with the $\mathrm{O}_{3}$ treatment as the main plot factor, and the varieties and transplanting density were the subplot factors. All data were subjected to an analysis of variance (ANOVA) using SPSS 12.0 software (SPSS Inc., Chicago, IL).

\section{Results}

\section{Nitrogen absorption}

The effects of $\mathrm{E}-\mathrm{O}_{3}$ on the $\mathrm{N}$ content in green leaves, stems, and spikes of each growth stage of Yangdao 6 and II You 084 rice varieties with different planting densities were similar. No significant effects of $\mathrm{E}-\mathrm{O}_{3}$ were observed on the $\mathrm{N}$ content of green leaves and spikes of both cultivars. Only the $\mathrm{N}$ content in the stems in all three stages was significantly increased in Yangdao 6 and II You $084(p \leq 0.05)$ (Table S1). Further, the N content in the shoots at jointing, heading, and maturity were greatly increased by $\mathrm{E}-\mathrm{O}_{3}$ (Table S2). In addition, $\mathrm{E}_{-} \mathrm{O}_{3}$ had no effect on the $\mathrm{N}$ accumulation in all stages of whole plant of Yaodao $6(p>0.05)$, whereas a decrease of $\mathrm{N}$ accumulation at all growth stages of the shoots of II You 084 was seen $(p \leq 0.05)$ (Table S3). Plant density had no significant effect on the $\mathrm{N}$ content and accumulation in organs and shoots under $\mathrm{O}_{3}$ stress (Table $\mathrm{S} 1-$ Table S3) $(p>0.05)$.

\section{$N$ distribution}

The $\mathrm{E}-\mathrm{O}_{3}$ had a decreasing effect on the $\mathrm{N}$ distribution in green leaves $(p \leq 0.05)$ of both cultivars, but exerted an increasing effect on $\mathrm{N}$ distribution in the stems $(p \leq 0.05)$. ANOVA revealed that the interaction between $\mathrm{O}_{3}$ concentration, variety, and density had significant effects on the $\mathrm{N}$ absorption ratio of cultivars at all growth stages $(p>0.05)$ (Table S4). 


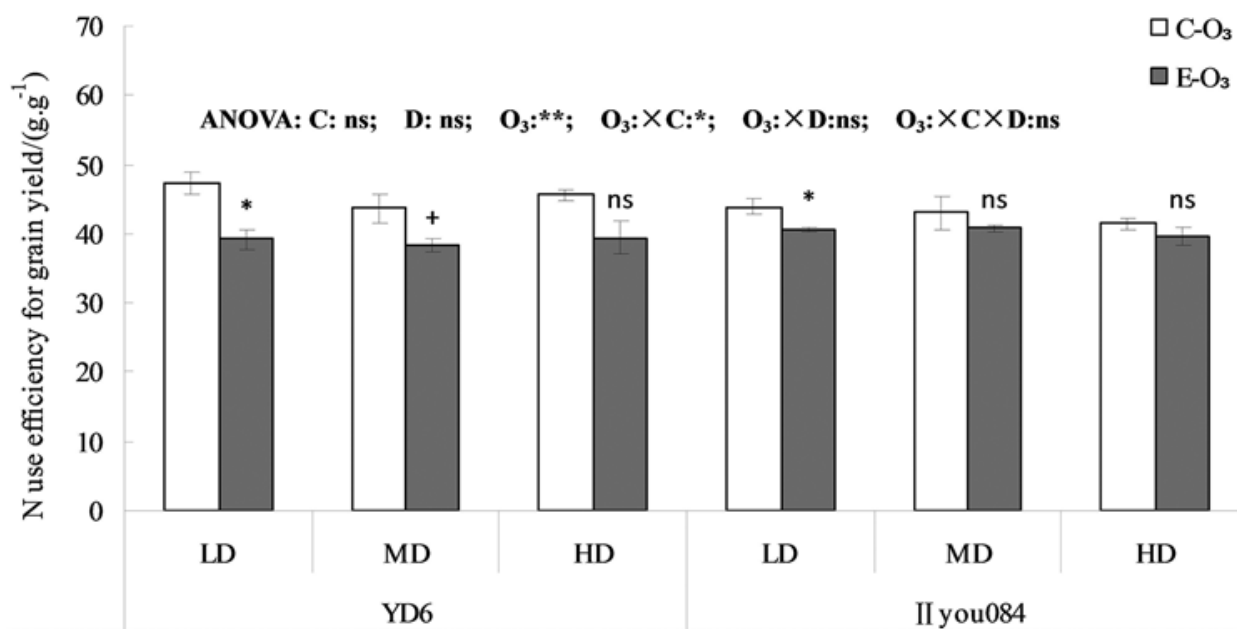

Figure 2. Effects of $\mathrm{E}-\mathrm{O}_{3}$ and plant density on the nitrogen use efficiency for grain yield of rice under free-air gas concentration enrichment. In the figure, $\mathrm{C}$ represents cultivar, D represents density, TS represents tillering stage, JS represents jointing stage, HS represents heading stage, and MS represents maturity stage. Two cultivars (Yangdao6 (YD6) and hybrid rice II You 084 (II You 084)) were cultured in low density (LD), medium density (MD), and high density (HD) and were exposed to the control $\mathrm{O}_{3}\left(\mathrm{C}-\mathrm{O}_{3}\right)$ and E- $\mathrm{O}_{3}$. Bars represent average values \pm standard errors

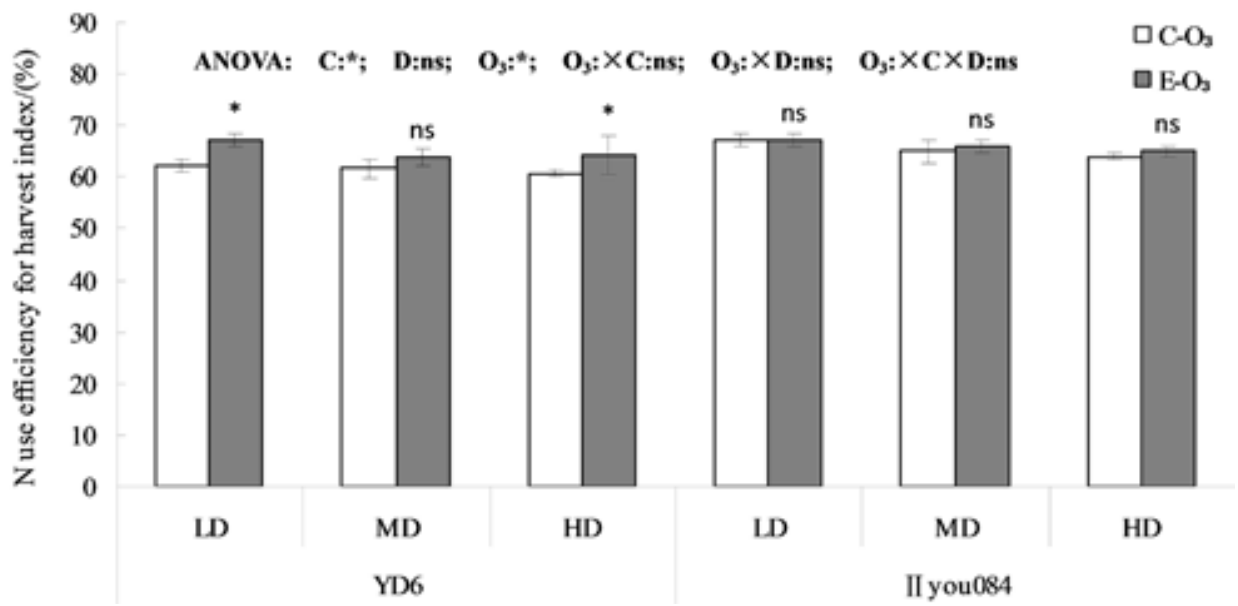

Figure 3. Effects of $\mathrm{E}_{-} \mathrm{O}_{3}$ and plant density on nitrogen use efficiency for harvest of rice under free-air gas concentration enrichment. In the figure, $\mathrm{C}$ represents cultivar, D represents density, TS represents tillering stage, JS represents jointing stage, HS represents heading stage, and MS represents maturity stage. Two cultivars (Yangdao6 (YD6) and hybrid rice II You 084 (II You 084)) were cultured in low density (LD), medium density (MD), and high density (HD) and were exposed to the control $\mathrm{O}_{3}\left(\mathrm{C}-\mathrm{O}_{3}\right)$ and $\mathrm{E}-\mathrm{O}_{3}$. Bars represent average values \pm standard errors 


\section{$N$ utilization}

E- $\mathrm{O}_{3}$ could significantly decrease NUE for biomass of cultivars in all stages (Fig. 1). The interaction between $\mathrm{E}_{-} \mathrm{O}_{3}$ and planting density had no significant effect on NUE, while interactions between $\mathrm{E}-\mathrm{O}_{3}$ and the varieties had significant effects on the NUE of cultivars in the maturity period (Fig. 1). Further, E- $\mathrm{O}_{3}$ decreased NUE for grain yield. Also, the interactions between $\mathrm{E}-\mathrm{O}_{3}$ and the varieties was significant for NUE of grain yield (Fig. 2). E-O E $_{3}$ increased NUE for the harvest of Yangdao $6(p \leq 0.05)$, but had no significant effect on that of II You $084(p>0.05)$ (Fig. 3).

\section{Discussion}

High $\mathrm{O}_{3}$ is taken up by plants through the stomata, causing great damage to the plants and affecting $\mathrm{N}$ absorption and utilization. Mulchi et al. (1986) and Pleijel et al. (1998) proposed that $\mathrm{E}_{-} \mathrm{O}_{3}$ increased $\mathrm{N}$ and protein contents of wheat grain. Similarly, Zheng et al. (2011) also revealed that $\mathrm{E}-\mathrm{O}_{3}$ could increase $\mathrm{N}$ content in rice components, but decrease the ratio of $\mathrm{N}$ and $\mathrm{C}$. Conversely, Richa et al. (2010) found that the $\mathrm{E}-\mathrm{O}_{3}$ decreased the $\mathrm{N}$ content of grains of NDR 97 and Saurabh 950 rice by 38.5\% and 5.6\%, respectively. Kou et al. (2017) also showed that elevated $\mathrm{O}_{3}$ decreased $\mathrm{N}$ production efficiency in grains of Sanyou 63 and Liangyoupeijiu. In the present study, we found that the $\mathrm{E}-\mathrm{O}_{3}$ could increase the $\mathrm{N}$ content in all of the organs of Yandao and hybrid rice II You 084, leading to the $\mathrm{N}$ content increasing in the shoots. Our results were in line with those of Zheng et al. (2011). It was speculated that high $\mathrm{N}$ content in plants under high $\mathrm{O}_{3}$ stress was an adaptive strategy for plants. High $\mathrm{N}$ content transformed by green leaves was found to contribute to improving defense and repair functions of plants (Maurer and Matysek 1997). Different cultivars exerted different $\mathrm{N}$ absorption and utilization under $\mathrm{O}_{3}$ stress, revealing that the effects of $\mathrm{O}_{3}$ were cultivar-dependent (Kou et al. 2017). Our studies also confirmed this by finding that the interaction between $\mathrm{E}-\mathrm{O}_{3}$ and the cultivars had a significant effect on the $\mathrm{N}$ absorption and utilization in Yangdao 6 and II You 084 (Table S1S3).

We also found that under $\mathrm{O}_{3}$ stress, the $\mathrm{N}$ content in the green leaves and grains of Yangdao 6 and II You 084 were greatly decreased, but increased in the stems, indicating that $\mathrm{E}-\mathrm{O}_{3}$ blocked $\mathrm{N}$ transport from stem to grain. Similarly, Zheng et al. (2011) also found that $\mathrm{E}-\mathrm{O}_{3}$ altered $\mathrm{N}$ concentrations in different tissues of the 3694Fan rice cultivar. Kou et al. (2017) observed that $\mathrm{E}_{-} \mathrm{O}_{3}$ blocked the $\mathrm{N}$ transport from roots to the culm but promoted $\mathrm{N}$ from the culm to the grain. These results revealed that $\mathrm{O}_{3}$ stress altered the translocation and reuse of endogenous mineral nutrients.

Both Yangdao 6 and II You 084 exerted similar decreasing NUE of dry matter production under ozone stress. Although total $\mathrm{N}$ represents protein-N and non-protein- $\mathrm{N}$, the $\mathrm{N}$ content in grain reflects the protein content to some degree. The NUE for grain output reflected the grain yield of uptaking unit $\mathrm{N}$. The $\mathrm{O}_{3}$ stress decreased $\mathrm{N}$ absorption and grain yield, with the latter having decreased greater than the former. Wang et al. (2014) found that elevated $\mathrm{CO}_{2}$ increased grain chalkiness and decreased mineral nutrient con- 
centration. Combined with our study, the harmful gas, $\mathrm{O}_{3}$, affects grain yield of rice. The $\mathrm{N}$ harvest index of rice reflected the ratio between the $\mathrm{N}$ absorption in grain and the total $\mathrm{N}$ of plant in the maturity stage. Our results showed that the $\mathrm{O}_{3}$ stress increased the $\mathrm{N}$ harvest index in Yangdao 6, which was in line with showing that $\mathrm{E}-\mathrm{O}_{3}$ could increase the $\mathrm{N}$ distribution ratio in the shoots of rice.

In conclusion, the effects of $\mathrm{O}_{3}$ stress on $\mathrm{N}$ absorption, distribution, and utilization were investigated in the present study. Our results revealed that the effects of $\mathrm{N}$ absorption and utilization were not influenced by planting density, but had a significant connection with cultivars. Further, $\mathrm{E}-\mathrm{O}_{3}$ blocked the $\mathrm{N}$ transport from stem to grain, suggesting that $\mathrm{N}$ fertilizer should be applied properly for Yangdao 6 and II You 084.

\section{Acknowledgements}

This study was supported by the Natural Science Foundation of Jiangsu Province (Grant No. BK20151298). We would like to thank Gao Liu, Haozhi Tang, and Xingguo Zhu, from the Nanjing Institute of Soil Science, Chinese Academy of Sciences, for their kindly daily maintenance of the ozone FACE system. We thank Dr. Qi Zhitao at the School of Marine and Biological Engineering, Yancheng Institute of Technology, for his helpful comments on the revised paper. We thank LetPub for its linguistic assistance during the preparation of this manuscript.

\section{References}

Ainsworth, E.A. 2008. Rice production in a changing climate: a metal analysis of responses to elevated carbon dioxide and elevated ozone concentration. Glob. Change Biol. 14:1-9.

Chen, J., Zeng, Q., Zhu, J.G., Liu, G., Xie, Z.B., Tang, H.Y., Kobayashi, K. 2011. Interactive effects of elevated ozone and nitrogen on dry matter production, concentration and accumulation of nitrogen, phosphorus and potassium in winter wheat. Ecol. \& Environ. 20:616-622 (in Chinese).

Chen, Z., Wang, X., Feng, Z., Zheng, F., Duan, X., Yang, W. 2008. Effects of elevated ozone on growth and yield of field-grown rice in Yangtze River Delta, China. Chin. J. Envir. Sci. 20:320-325.

Feng, Z.Z., Kobayashi, K. 2009. Assessing the impacts of current and future concentrations of surface ozone on crop yield with meta-analysis. Atmos. Environ. 43:1510-1519.

Jin, M.H., Feng, Z.W., Zhang, F.Z. 2001. Impacts of ozone on the biomass and yield of rice in open-top chambers. Chin. J. Envir. Sci. 13:233-236.

Kou, T.J., Wang, L.R., Zhu, J.G., Xie, Z.B., Wang, Y.L. 2014. Ozone pollution influences soil carbon and nitrogen sequestration and aggregate composition in paddy soils. Plant Soil 380:305-313.

Kou, T.J., Xu, G.W., Zhu, J.G. 2017. Impact of elevated ozone on nutrient uptake and utilization of Chinese hybrid indica rice (Oryza sativa) cultivars under free-air ozone enrichment. Commun. Soil Sci. Plan. 48:635-645.

Luo, K.J., Zhu, J.G., Liu, G., Tang, H.Y., Li, C.H., Zeng, Q. 2012. Effects of elevated ozone on leaf photosynthesis of rice (Oryza sativa L.) and mitigation with high nitrogen supply. Ecol. \& Environ. 21:481-488 (in Chinese).

Long, S.P., Ainsworth, E.A., Leakey, A.D.B., Morgan, P.B. 2011. Global food insecurity. Treatment of major food crops with elevated carbon dioxide or ozone under large-scale fully open air conditions suggests recent models may have overestimated future yields. Philosophical Transactions of the Royal Society B: Biological Sciences 360:2011-2020. 
Maurer, S., Matyssek, R. 1997. Nutrition and the ozone sensitivity of birch (Betula pendula) carbon balance, water-use efficiency and nutrition status of the whole plant. Trees 12:11-20.

Mulchi, C.L., Sammons, D.J., Baenziger, P.S. 1986. Yield and grain quality responses of soft red winter wheat exposed to ozone during anthesis. Agron. J. 78:593-600.

Pang, J., Kazuhiko, K. 2009. Yield and photosynthetic characteristics of flag leaves in Chinese rice (Oryza sativa L.) varieties subjected to free-air release of ozone. Agr. Ecosyst. Environ. 132:203-211.

Pleijel, H., Danielsson, H., Gelang, J., Sild, E., Selldén, G. 1998. Growth stage dependence of the grain yield response to ozone in spring wheat (Triticum aestivum L.). Agr. Ecosyst. Environ. 70:61-68.

Richa, R., Madhoolika, A., Agrawal, S.B. 2010. Threat to food security under current levels of ground level ozone: A case study for Indian cultivars of rice. Atmos. Environ. 44:4272-4282.

Shao, M., Tang, X., Zhang, Y., Li, W. 2006. City clusters in China: air and surface water pollution. Front. Ecol. Environ. 4:353-361.

Tong, L., Wang, X.K., Xiao, H., Huang, Z.W. 2015. The effects of surface ozone on the yields of rice and winter wheat in China. Asian Journal of Ecotoxicology 10:161-169.

Wang, Y.X., Song, Q.L., Frei, M., Shao, Z.S., Yang, L.X. 2014. Effects of elevated ozone, carbon dioxide, and the combination of both on the grain quality of Chinese hybrid rice. Environ. Pollut. 189:9-17.

Wu, W., Shah, F., Shah, F., Huang, J.L. 2015. Rice sheath blight evaluation as affected by fertilization rate and planting density. Australas. Plant Path. 44:183-189.

Yang, L.X., Wang, Y.L., Shi, G.Y., Wang, Y.X., Zhu, J.G., Kobayashi, K., Lai, S.K. 2008. Responses of rice growth and development to elevated near-surface layer ozone $\left(\mathrm{O}_{3}\right)$ concentration: A review. Chin. J. Appl. Ecol. 19:901-910.

Zeng, N., Ding, Y., Pan, J., Wang, H., Gregg, J. 2008. Climate change - the Chinese challenge. Science 319:730-731.

Zheng, F.X., Wang, X.K., Hou, P.Q., Zhang, W., Lu, F. 2011. Influences of elevated ozone on growth and C, N, S allocations of rice. Acta Ecol. Sin. 31:1479-1486 (in Chinese).

Zhao, Y.P., Shao, Z.S., Wang, Y.X., Song, Q.L., Wang, Y.L., Yang, L.X. 2015. Impact of elevated atmospheric carbon dioxide and ozone concentration on growth dynamic, dry matter production, and nitrogen uptake of hybrid rice Shanyou 63. Acta Ecol. Sin. 35:8128-8138 (in Chinese).

\section{Electronic Supplementary Material (ESM)}

Electronic Supplementary Material (ESM) associated with this article can be found at the website of CRC at https://akademiai.com/loi/0806

Electronic Supplementary Table S1. Effects of surface ozone concentration and plant density on N concentration in the organs of rice under FACE condition

Electronic Supplementary Table S2. Effects of surface ozone concentration and plant density on N concentration in shoot under FACE condition

Electronic Supplementary Table S3. Effects of surface ozone concentration and plant density on N accumulation in plant of rice under FACE condition

Electronic Supplementary Table S4. Effects of surface ozone concentration and plant density on N distribution ratio in the organs of rice under FACE condition

Electronic Supplementary Figure S1. The change of day time 7-h mean ozone concentration during ozone fumigation. $\mathrm{C}_{-} \mathrm{O}_{3}$ : Current $\mathrm{O}_{3}$ concentration; $\mathrm{E}-\mathrm{O}_{3}$ : Elevated $\mathrm{O}_{3}$ concentration (up: 2011; down: 2012) 